\title{
Efficacy of light therapy on nonseasonal depression among elderly adults: a systematic review and meta-analysis [Corrigendum]
}

Chang CH, Liu CY, Chen SJ, Tsai HC. Neuropsychiatr Dis
Treat. 2018;14:3091-3102.

The authors have advised that they listed the second affiliation in the author list of the paper incorrectly.
The current affiliation number 2 "Department of Psychiatry \& Brain Disease Research Center, China Medical University Hospital, Taichung, Taiwan" should instead appear as "An Nan Hospital, China Medical University, Tainan, Taiwan".

\section{Publish your work in this journal}

Neuropsychiatric Disease and Treatment is an international, peerreviewed journal of clinical therapeutics and pharmacology focusing on concise rapid reporting of clinical or pre-clinical studies on a range of neuropsychiatric and neurological disorders. This journal is indexed on PubMed Central, the 'PsycINFO' database and CAS, and is the official journal of The International Neuropsychiatric Association (INA). The manuscript management system is completely online and includes a very quick and fair peer-review system, which is all easy to use. Visit http://www.dovepress.com/testimonials.php to read real quotes from published authors. 